\title{
Invasive species and bushmeat hunting contributing to wildlife conservation: the case of feral pigs in a Neotropical wetland
}

\author{
Arnaud Leonard Jean Desbiez, Alexine Keuroghlian \\ UBirata PIOVEZAN and RICHARD ERNEST BODMER
}

\begin{abstract}
An unusual combination of two major conservation threats, invasive species and bushmeat hunting, has had a positive outcome for wildlife conservation in the Brazilian Pantanal. The Pantanal is a wetland and one of the few non-protected areas in the Neotropics where people live but rarely hunt native wildlife. To understand why wildlife hunting is not a major conservation issue in the Pantanal an exploratory survey, semi-structured interviews, skull collection and tooth wear analysis of feral pig Sus scrofa, white-lipped peccary Tayassu pecari and collared peccary Pecari tajacu were conducted, and hunting registers distributed, in the central region of the Pantanal. The results showed that feral pigs are the main hunting target. Feral pigs are effectively acting as a replacement species for hunting of native wildlife because the pigs provide a constant, culturally acceptable, readily available and free source of meat and oil to remote ranches. We cannot evaluate, however, if the buffer from hunting that feral pigs provide to native wildlife outweigh this species' potential negative ecological impacts.
\end{abstract}

Keywords Brazil, Bushmeat, feral pig, hunting, invasive species, Pantanal, Sus scrofa

\section{Introduction}

The introduction of exotic species is second only to 1 habitat loss as a cause of species endangerment and extinction (Lowe et al., 200o) and hunting of, and trade in, wildlife species for consumptive purposes have resulted in population declines both within and outside protected areas throughout the tropics (Redford, 1992; Fa et al., 2002). Here, however, we describe how the unusual combination of the

Arnaud Leonard Jean Desbiez (Corresponding author) Royal Zoological Society of Scotland, Conservation and Research Department, Murrayfield, Edinburgh, EH12 6TS, UK, and Embrapa Pantanal, Corumbá, Mato Grosso do Sul, Brazil. E-mail adesbiez@rzss.org.uk

Alexine Keuroghlian Wildlife Conservation Society-Brazil, Rio de Janeiro, Brazil

Ubiratan Piovezan Embrapa Pantanal, Corumbá, Mato Grosso do Sul, Brazil

Richard ERnest Bodmer Durrell Institute of Conservation and Ecology, University of Kent, Canterbury, Kent, UK

Received 3 September 2009. Revision requested 6 November 2009. Accepted 7 January 2010. introduction of an exotic species and the hunting of it has a positive outcome for wildlife conservation in the Brazilian Pantanal. The Pantanal, which lies mostly within Brazil but also extends into Bolivia and Paraguay, is one of the world's largest freshwater wetlands and is famous for its unique abundance of conspicuous wildlife. In the Brazilian Pantanal $95 \%$ of the land is privately owned and thus abundance of wildlife cannot be credited to protected areas. The main economic activity in the region is extensive cattle ranching and, under traditional management practices, this activity is reported to have a lower impact on biodiversity than other forms of land use in the tropics (Seidl et al., 2001). However, in many areas of the world's pristine habitats, even with low human population densities, abundance of wildlife has been greatly reduced by hunting (Redford, 1992; Rosser \& Mainka, 2002; Milner-Gulland et al., 2003).

One of the main reasons for the abundance of wildlife in the Brazilian Pantanal is that, other than persecution of large felids by cattle ranchers (Zimmermann et al., 2005), hunting and poaching are no longer common (Harris et al., 2005). Commercial hunting was formerly a major concern in the Pantanal but commercial or recreational hunting of native species is now illegal (Brazilian Fauna Protection, Law No 5197, January 1967) and the pelt and skin trade markets are no longer available.

The purpose of this study was to investigate and understand hunting practices in the Pantanal flood plain. We argue that one of the reasons hunting is not a conservation issue in the Pantanal is that local people prefer to hunt the feral pig Sus scrofa rather than native wildlife. Pigs were introduced to the Pantanal $>200$ years ago, probably as escapees that became feral during the Paraguay War (18651870), when ranches in the Pantanal were devastated and abandoned. Feral pigs now occur throughout the flood plain (Mourão et al., 2002). We examine how an introduced species is successfully diluting the hunting pressure on native wildlife.

\section{Methods}

We interviewed local people throughout the central Pantanal (Fig. 1). Hunting registers were distributed in the region, and skulls were collected at the Embrapa Pantanal Nhumirim ranch $\left(18^{\circ} 59^{\prime} \mathrm{S}, 56^{\circ} 37^{\prime} \mathrm{W}\right)$ and six surrounding ranches covering an area of $400 \mathrm{~km}^{2}$. The region, ranches 


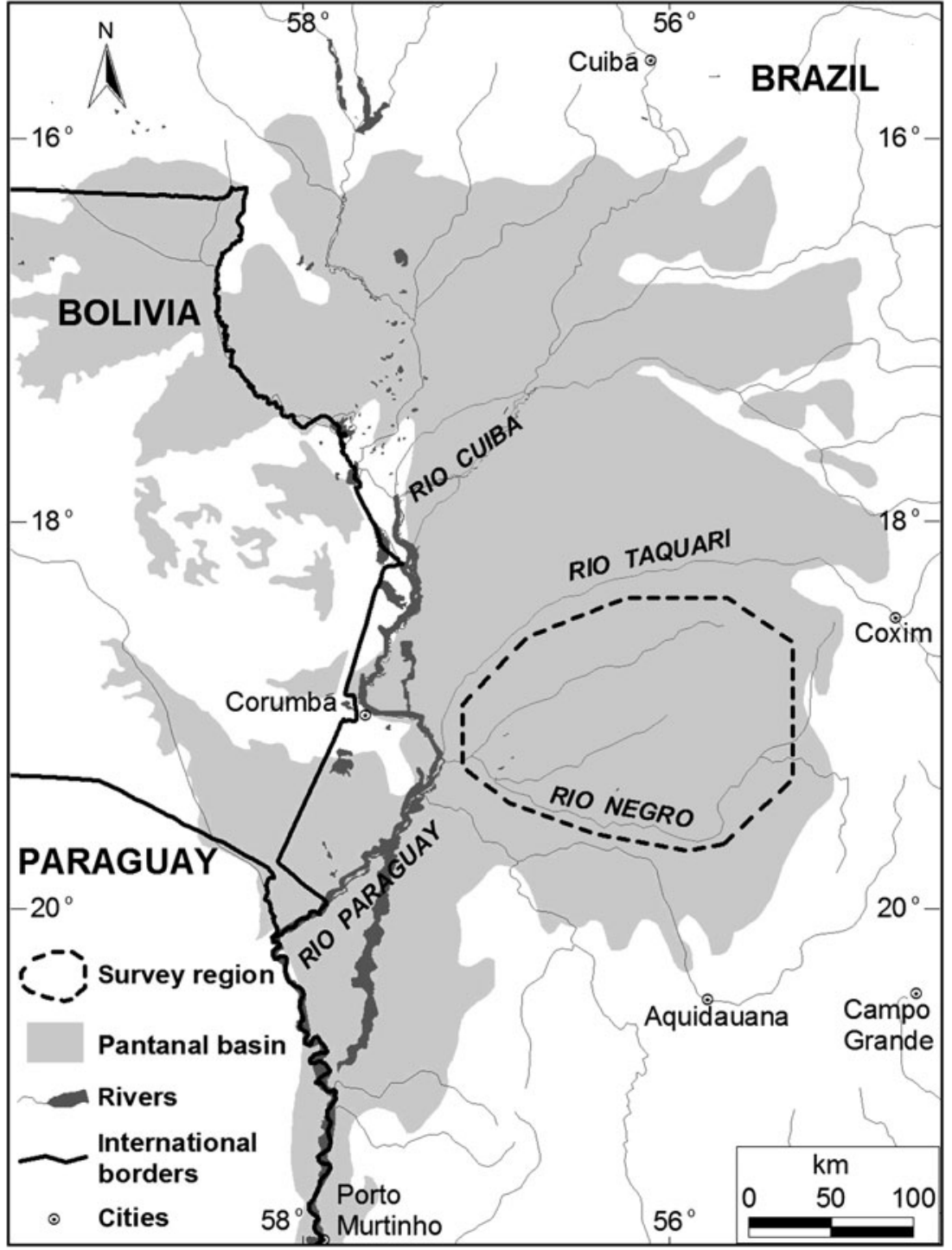

FIG. 1 The Pantanal and the central region between the Rio Taquari and Rio Negro where 71 ranches where visited. and wildlife are described in Desbiez et al. (2010). Semistructured interviews were based on an exploratory survey conducted in the region between July 2002 and December 2003 that focused on hunting practices and customs. These interviews were designed as conversations guided towards topics of interest while remaining flexible enough to include input or related topics of interest from the interviewee. A total of 97 interviews were conducted between April 2004 and November 2005. Interviews took place at 71 different ranches (1-3 interviews per ranch).

Hunting registers, collection of skulls and tooth wear analysis were used to verify the verbal reports of hunting behaviour. An easy-to-use register was developed. It was based on drawings on which respondents simply needed to tick an image. Registers identified the sex, reproductive and physical condition of the animal hunted as well as the method used to kill it (Fig. 2). These drawings were distributed to hunters between January 2003 and November
2005. Hunting registers were retrieved from six ranches, documenting on average 11 months of hunting activities and the harvest of a total of 192 feral pigs. White-lipped peccary Tayassu pecari, collared peccary Pecari tajacu and feral pig skulls were collected serendipitously during 20022004 in the area surrounding the Nhumirim ranch. We believe that most of the skulls of animals that either died of natural causes or were hunted in the study area were collected. After killing a feral pig, hunters typically cut-off the animal's head and feet, and discard, to facilitate carrying the carcass back to the ranch on horseback. A total of 255 skulls $>1$ year of age, with evidence of adult dentition, were collected. Tooth wear analysis for the three species used the classification of Bodmer et al. (1997): Class I, adult dentition incomplete; Class II, adult dentition complete with little wear; Class III, adult dentition complete and shows signs of wear; Class IV, adult dentition is complete and very worn. 


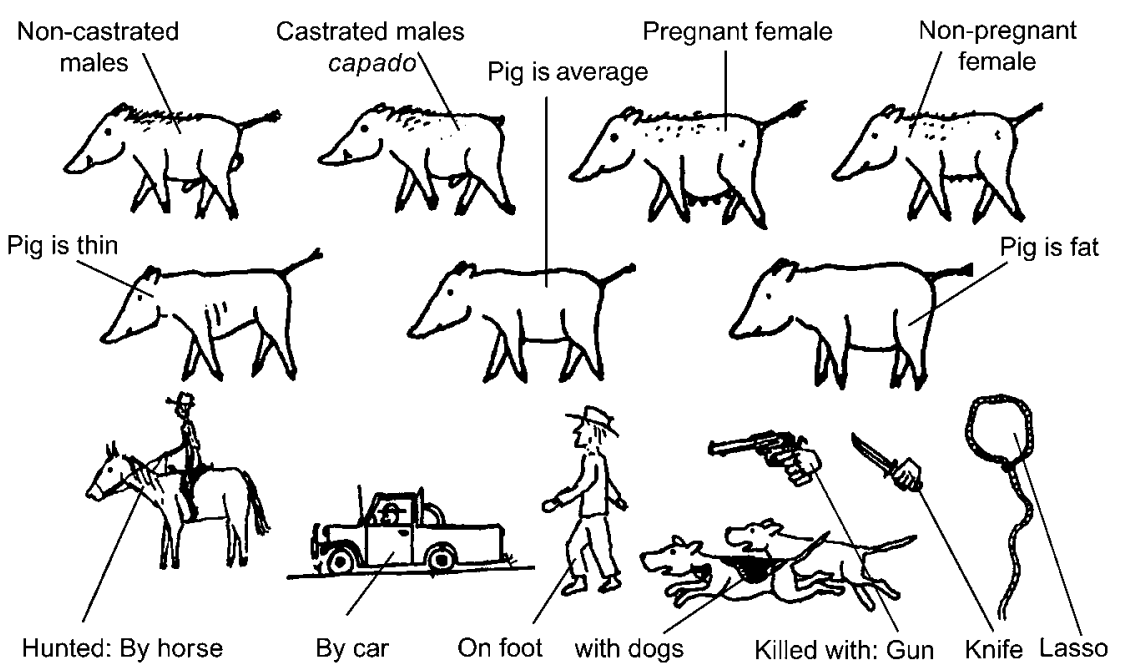

FIG. 2 Register, using drawings, for the hunting of feral pig Sus scrofa. Ticks on the appropriate drawings indicated the sex, reproductive status and condition, and the method by which the animal was killed.

\section{Results}

Feral pigs are the main hunting target

Results from the exploratory survey, semi-structured interviews, collection of skulls and tooth wear analysis all confirmed that feral pigs are the main hunting target in the region. On the 71 ranches visited for the semi-structured interviews, feral pigs were hunted (100\%) and were the favoured hunting target. Other species were rarely hunted: $18 \%$ of the hunters interviewed mentioned having hunted white-lipped peccaries, $13 \%$ collared peccaries, $13 \%$ armadillos (Dasypus and Euphractus), 7\% birds and 2\% other species in the past 5 years. The interviews focused on hunting for consumption but it was clear that carnivores are regularly persecuted. Local people reported that big cats are usually shot when encountered. Most of the respondents (93\%) said that feral pigs were their favourite wild meat, and only $7 \%$ mentioned white-lipped peccaries as their meat of choice.

In the area where skulls were collected the density of both species of peccaries was higher than that of the feral pig (Desbiez et al., 2010), yet most of the skulls collected belonged to feral pigs. Of the 255 skulls collected, $87 \%$ were of feral pigs (222), 7.5\% of white-lipped peccaries (19) and $5.5 \%$ of collared peccaries (14).

Relative age class patterns at death of feral pigs and peccaries in the Pantanal were significantly different $(F=$ $58.74, \mathrm{df}=3, \mathrm{P}<0.001$; Fig. 3). Tooth wear analysis of the peccary skulls from this study and from peccary skulls collected in the Pantanal by Schaller (1983) shows a characteristic age-related mortality pattern. Proportions between age classes are significantly different $(F=6.587, \mathrm{df}=2, \mathrm{P}=$ $0.017)$ and mortality of animals from the youngest age class (Class I + II) is lower than that from the oldest age class (Class IV; pairwise multiple comparison procedure with Tukey test, $\mathrm{P}=0.021)$. Tooth wear analysis of feral pigs from the study area shows the opposite trend. Almost twice as many skulls collected belonged to the youngest rather than the oldest age class (Tukey test, $\mathrm{P}<0.001$ ). Relative age class patterns at death of feral pig populations were similar to those of hunted white-lipped peccary populations in Peru (Bodmer et al., 1997; Fig. 3). Values of Class I + II $(t=0.210, \quad \mathrm{df}=3, \mathrm{P}=0.847)$, Class III $(t=4, \mathrm{n}=5$, $\mathrm{P}=0.4)$ and Class IV $(t=3.109, \mathrm{df}=3, \mathrm{P}=0.053)$ for the feral pigs and hunted white-lipped peccaries were comparable. Mortality rates of feral pigs in the Pantanal and hunted white-lipped peccaries in Peru are different from that of the peccaries of the Pantanal, Class I + II $(t=11.291$, $\mathrm{df}=7, \mathrm{P}<0.001)$ and Class IV $(t=5.891, \mathrm{df}=7, \mathrm{P}<0.001$; Bodmer et al., 1997). Peccaries in the Pantanal have a characteristic age-related mortality pattern, whereas the feral pig has a mortality pattern that characterizes hunted animals.

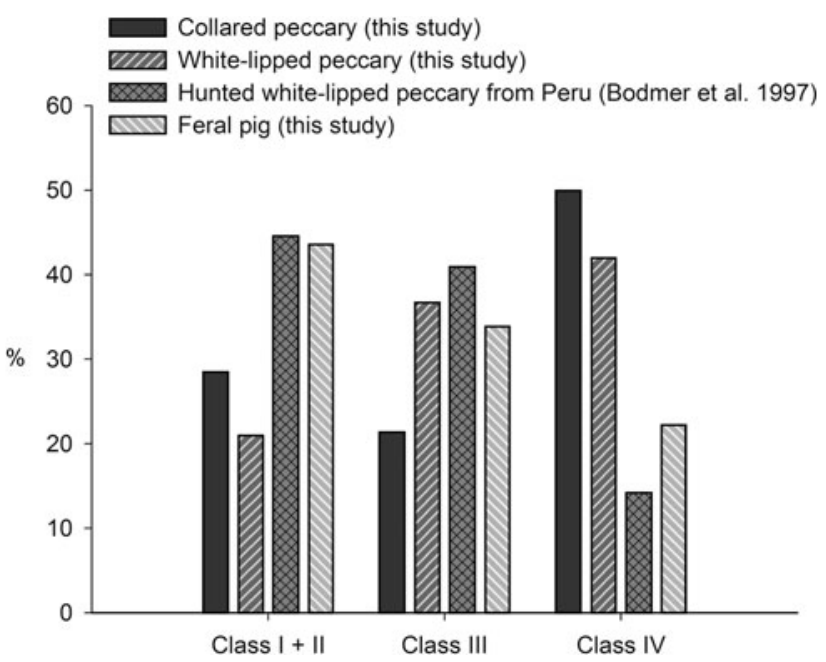

FIG. 3 Proportion of skulls of age class categories I+II, III and IV (see text for details) of collared peccary Pecari tajacu and whitelipped peccary Tayassu pecari and feral pig skulls collected in this study, and of hunted white-lipped peccaries from the Peruvian Amazon (Bodmer et al., 1997). 


\section{A widely practised traditional activity}

One of the most remarkable aspects of feral pig hunting is the harvest of previously castrated male feral pigs. Ranch workers catch young male feral pigs and castrate, mark and then release them. Castrated males heal, gain weight and are killed later. Hunters estimate that it takes at least 6-10 months for the animal to heal and fatten up. A fat castrated male, locally referred to as a capado, is the main target of all hunting expeditions but, if one is not located, then a female may be killed. Many hunters claim to take care not to kill pregnant feral pigs. Non-castrated males are sometimes killed, but their strong-tasting meat is generally fed to the dogs. This information was confirmed by results from the hunting registers (Table 1). There was no significant difference between number of males (102) and females (90) harvested $(t=132, \mathrm{n}=12, \mathrm{P}=0.312)$, but castrated males (91) were selected over non-castrated males (11; $t=220$, $\mathrm{n}=12, \mathrm{P}<0.001$ ) and non-pregnant females (86) were selected over pregnant females (four; $t=78, \mathrm{n}=12$, $\mathrm{P}<$ o.001).

Hunting practices were reported consistently throughout the 97 interviews. Generally, hunting is on horseback (100\%), with dogs (84\%) and using a lasso and a knife or gun. Use of a gun depends on ownership of a gun as well as the area hunted and the difficulty of the hunt. In open flood plains animals can be lassoed and then stabbed. In closed forested areas the feral pig is usually shot. Dogs will find and flush out groups of feral pigs in forested areas. The hunting registers confirmed these results, with $93.6 \%$ of the feral pigs killed from horseback, $1.4 \%$ from a car and $5 \%$ on foot, and dogs were used in $95 \%$ of the hunts.

Hunting usually occurs on the ranch property, requires transporting the animal back to the settlement and is usually done during a ranch worker's free time. On average, 3.3 feral pigs were killed per month according to the registers (Table 1 )

TABLE 1 Seasonal variation in mean monthly harvest of feral pigs at six ranches in the central Pantanal (Fig. 1), separately for the wet and dry seasons, as reported with hunting registers (Fig. 2).

\begin{tabular}{lllllll}
\hline \multirow{2}{*}{$\begin{array}{l}\text { Ranch } \\
\text { ID }\end{array}$} & Season & $\begin{array}{l}\text { Non- } \\
\text { castrated } \\
\text { male }\end{array}$ & $\begin{array}{l}\text { Castrated } \\
\text { male }\end{array}$ & $\begin{array}{l}\text { Pregnant } \\
\text { female }\end{array}$ & Female & Total \\
\hline 1 & Wet & 0.5 & 3.0 & 0.3 & 1.3 & 5.0 \\
& Dry & 0.3 & 1.8 & 0.0 & 1.3 & 3.5 \\
2 & Wet & 0.0 & 3.0 & 0.0 & 1.0 & 4.0 \\
& Dry & 0.2 & 1.2 & 0.2 & 1.5 & 3.0 \\
4 & Wet & 0.0 & 2.0 & 0.0 & 1.3 & 3.3 \\
& Dry & 0.2 & 1.2 & 0.0 & 1.2 & 2.6 \\
6 & Wet & 0.3 & 1.7 & 0.3 & 3.0 & 5.3 \\
& Dry & 0.0 & 1.0 & 0.0 & 1.0 & 2.0 \\
9 & Wet & 0.5 & 1.5 & 0.0 & 2.5 & 4.5 \\
& Dry & 0.2 & 1.4 & 0.0 & 1.6 & 3.2 \\
A1 & Wet & 0.3 & 0.7 & 0.0 & 1.0 & 2.0 \\
& Dry & 0.0 & 0.4 & 0.1 & 0.8 & 1.3 \\
\hline
\end{tabular}

and 2.6 according to the semi-structured interviews (Table 2). Harvest rates are highly variable between ranches and vary between seasons and needs. Most hunters claimed they prefer hunting during the wet season $(67 \%)$ when pigs are fat because of their consumption of fruits. Hunting registers confirmed that more feral pigs were killed during the wet season than the dry season $(t=2.36, \mathrm{df}=10, \mathrm{P}=0.040$; Table 1). Hunting generally occurs when meat is required but castration of feral pigs takes place opportunistically while ranch workers are tending cattle. The number of pigs castrated per month is more than seven times the number of castrated pigs killed per month (Table 2).

\section{Importance of hunting}

Feral pig meat and fat are an important and appreciated part of the diet of people living in the Pantanal. Hunters select the feral pigs they harvest. All 97 respondents explained that corpulence was the main selection criteria. Results from hunting registers confirmed that fat animals were significantly selected over animals of normal weight $(t=16.206, \mathrm{df}=8, \mathrm{P}<0.001)$. Of the 192 recorded harvests, $85.6 \%$ were described as fat and $14 \%$ as normal, and none were considered thin. Feral pigs, particularly large capados, are especially valued for their fat. Fat is removed from the carcass and then fried and used as cooking oil. A fat capado can yield 20-30 1 of fat. Feral pig fat is economically important because in $58 \%$ of the ranches surveyed cooking oil was not provided by the landowner. Ranch workers would need to purchase cooking oil from the towns (c. USD $\left.1.5 \mathrm{l}^{-1}\right)$. Consequently, most ranches only use feral pig fat for cooking oil and to store meat. This is especially useful for ranches without electricity because fried meat can be preserved for several months when stored in feral pig fat in a tin container.

Landowners generally provide beef for ranch hands. Workers living on ranches without electricity and freezers commonly consume dried beef. Feral pigs are an important source of fresh meat and a change from beef. Feral pig meat was consumed at least once (95\%) per month or several $(62 \%)$ times per month. Cows are not slaughtered when it is

TABLE 2 Mean number of pigs hunted and castrated per month, based on information from interviews, at 71 ranches in the central Pantanal (Fig. 1), and the ratio of pigs castrated to castrated pigs hunted.

\begin{tabular}{llll}
\hline & $\begin{array}{l}\text { Pigs hunted } \\
\text { per month }\end{array}$ & $\begin{array}{l}\text { Pigs castrated } \\
\text { per month }\end{array}$ & $\begin{array}{l}\text { Proportion of pigs } \\
\text { castrated / castrated } \\
\text { pigs hunted }\end{array}$ \\
\hline Mean & 2.57 & 10.85 & 7.60 \\
SD & 1.89 & 11.04 & 6.19 \\
Min. & 0.50 & 2.00 & 2.00 \\
Max. & 10.00 & 60.00 & 30.00 \\
$\mathrm{n}$ & 67 & 51 & \\
\hline
\end{tabular}


raining because the meat cannot be dried, and feral pig meat is consumed until a cow can be killed. Feral pigs are therefore a source of food security for times when other meat is unavailable. They are often eaten during barbecues on Sundays, special holidays or during local regional festivities. Feral pigs have thus become a traditional part of the diet in the Pantanal.

\section{Hunters' perceptions}

Feral pig hunting and castration is a highly valued traditional activity. Hunting skills, harvest frequency, number of males castrated and size of animal hunted are highly regarded achievements. A good hunter is admired. Hunting feral pigs is an important source of leisure in these isolated ranches where there are few distractions. Practices, beliefs and even hunting stories are extremely popular and similar across the Pantanal. Hunting is considered an important social activity and $73 \%$ of hunts usually involve two or more hunters. Harvested meat is always shared among the ranch hands and strengthens friendships between individuals and families on the ranch.

Forty-eight percent of local people interviewed claimed that feral pigs have a positive impact for the ranch and environment. None of the interviewees claimed that feral pigs have a negative impact but $52 \%$ mentioned that their presence could have both positive and negative impacts on the environment. When populations of feral pigs become abundant, negative impacts include uprooting of fields, destroying pasture (particularly around ponds) and digging holes, which can cause horseback riding accidents. On 10\% of the ranches large males were reported to sometimes kill newborn calves or lambs.

\section{Discussion}

Feral pigs in the Pantanal flood plain represent an unusual situation for conservation biology. Introduction of an invasive species and bushmeat hunting, two major threats to biodiversity, are aiding wildlife conservation. All the methods used (the exploratory survey, semi-structured interviews, collection of skulls, tooth wear analysis and hunting registers), showed that feral pigs are currently the main hunting target for people living and working in the central Pantanal. Feral pigs are one of the largest mammals in the region and the traditional practice of castrating young males increases the weight of pigs, supply of cooking oil and meat per animal harvested. Feral pigs are abundant because of their high intrinsic growth rate (Desbiez, 2009a). In addition, hunters target males and avoid pregnant females, decreasing the impact of hunting on population growth.

Throughout the Neotropics, unless an area is well protected or difficult to access, peccaries, deer Mazama sp., tapir Tapirus sp. and capybara Hydrochoerus hydrochaeris are hunted and are an important source of animal protein or income (Robinson \& Bennett, 2000). The Brazilian Pantanal is one of the few unprotected regions in the Neotropics where people live but rarely hunt such species. Feral pigs are acting as a replacement species for hunting of native wildlife because they provide a constant, culturally acceptable, readily available and free source of meat and oil to isolated ranches.

The Pantanal has been affected by exotic cattle, horses, buffaloes, sheep and pigs for more than two centuries and native wildlife appears to have adapted to their presence without being driven to extinction. Feral pigs are recognized as one of the world's most destructive and invasive introduced species (Lowe et al., 2000) but this does not seem to be the case in the Pantanal flood plain. It was previously suspected that feral pigs may compete with the native whitelipped and collared peccaries but in a niche partitioning study it was found that overlap in food resources and habitat use between feral pigs and peccaries was lower than expected (Desbiez et al., 2009b,c; Keuroghlian et al., 2009a). Differences in morphology and behaviour indicate possible mechanisms of niche partitioning between the species (Desbiez \& Keuroghlian, 2009; Desbiez et al., 2009b).

Feral pigs may, nevertheless, have other affects. In the Pantanal they may be reservoirs of disease (Herrera et al., 2008; Paes et al., 2009), predate eggs of ground nesting birds (Desbiez et al., 2009b) and reptiles (Campos, 1993), and alter plant communities through their rooting activities (Desbiez et al., 2009b). In particular, feral pigs heavily predate Attalea phalerata palms in their early growth stage during the dry season (Desbiez et al., 2009d). This palm is one of the key resources for frugivores in the region (Desbiez, 2007; Keuroghlian et al., 2009b). There is concern that the impact of feral pigs may change if traditional hunting practices are abandoned and the landscapes in the Pantanal are transformed by human activities (Desbiez et al., 2009b; Keuroghlian et al., 2009a). The ecological impact of feral pigs is still poorly understood. We therefore cannot answer the critical question: does the buffering from hunting that feral pigs provide to native wildlife outweigh the negative impacts of the species on potential resource competition, habitat degradation and disease transmission? Experimental and ecological work are required to address this question. Currently, feral pigs are an established component of the Pantanal fauna and there appears to be a conservation benefit from their presence. The presence of this exotic species should, however, be monitored so that negative and positive outcomes can be better understood.

\section{Acknowledgements}

This work was a collaboration between the Durrell Institute of Conservation and Ecology and Embrapa Pantanal. This study was part of the $\mathrm{PhD}$ thesis of ALJD who received funding from the European Union INCO PECARI project. 
The last year of fieldwork was funded by the Royal Zoological Society of Scotland and Embrapa Pantanal (project 02.02.5.25). AK received funds from the Earthwatch Institute. We thank the ranch workers throughout the Pantanal for their patience during the interviews, D.P. Eaton for the map and an anonymous reviewer for comments.

\section{References}

Bodmer, R.E., Aquino, R., Puertas, P.E., Reyes, C.J., Fang, T.G. \& Gottendenker, N.L. (1997) Manejo y uso Sustentable de pecaries en la Amazonia Peruana. Occasional Paper of the IUCN Species Survival Commission No.18 IUCN-Sur Quito, Ecuador y Secretaria CITES, Geneva, Switzerland.

Campos, Z.M.S. (1993) Effect of habitat on survival of eggs and sex ratio of hatchlings of caiman (Crocodilus yacare) in the Pantanal, Brazil. Journal of Herpetology, 27, 127-132.

Desbiez, A.L.J. (2007) Wildlife conservation in the Pantanal: habitat alteration, invasive species and bushmeat hunting. $\mathrm{PhD}$ thesis. Durrell Institute of Conservation and Ecology, University of Kent, Canterbury, UK.

Desbiez, A.L.J., Bodmer, R.E. \& Santos, S.A. (2009c) Wildlife habitat selection and sustainable resources management in a Neotropical wetland. International Journal of Biodiversity and Conservation, 1, 11-20.

Desbiez, A.L.J., Bodmer, R.E. \& Tomas, W.M. (2010) Mammalian densities in a neotropical wetland subject to extreme climatic events. Biotropica, 42, 372-78.

Desbiez, A.L.J. \& Keuroghlian, A. (2009) Can bite force be used as a basis for niche separation between native peccaries and introduced feral pigs in the Brazilian Pantanal? Mammalia, 73, 369-372.

Desbiez, A.L.J., Keuroglian, A., Piovezan, U. \& Bodmer, R. E. (2009a) Ecologia de populações de porco monteiro no Pantanal do Brasil. Documento no. 106. Embrapa Pantanal, Corumbá, Brazil.

Desbiez, A.L.J. Santos, S.A. \& Keuroghlian, A. (2009d) Predation of young palms (Attalea phalterata) by feral pigs in the Brazilian Pantanal. Suiform Soundings, 9, 35-40.

Desbiez, A.L.J., Santos, S.A., Keuroghlian, A. \& Bodmer, R.E. (2009b) Niche partitioning among white-lipped peccaries (Tayassu pecari), collared peccaries (Pecari tajacu), and feral pigs (Sus scrofa). Journal of Mammalogy, 90, 119-128.

FA, J.E., Peres, C.A. \& Meeuwig, J. (2002) Bushmeat exploitation in tropical forests: an intercontinental comparison. Conservation Biology, 16, 232-237.

Harris, M.B., Tomás, W.M., Mourão, G., Da Silva, C.J., Guimarães, E., Sonoda, F. \& Fachim, E. (2005) Safeguarding the Panatanal wetlands: threats and conservation initiatives. Conservation Biology, 19, 714-720.

Herrera, H.M., Abreu, U.G.P., Keuroghlian, A., Freitas, T.P. \& JANSEN, A. (2008) The role played by sympatric collared peccary (Tayassu tajacu), white-lipped peccary (Tayassu pecari), and feral pig (Sus scrofa) as maintenance hosts for Trypanosoma evansi and Trypanosoma cruzi in a sylvatic area of Brazil. Parasitological Research, 103, 619-624.

Keuroghlian, A., Eaton, D.P. \& Desbiez, A.L.J. (2009a) Habitat use by peccaries and feral pigs of the southern Pantanal, Mato Grosso do Sul, Brazil. Suiform Soundings, 8, 9-16.

Keuroghlian, A., Eaton, D.P. \& Desbiez, A.L.J. (2009b) The response of a landscape species, white-lipped peccaries, to seasonal resource fluctuations in a tropical wetland, the Brazilian Pantanal. International Journal of Biodiversity and Conservation, $1,87-97$.

Lowe, S., Browne, M., Boudjelas, S. \& De Poorter, M. (2000) 100 of the World's Worst Invasive Alien Species. A Selection from the Global Invasive Species Database. Species Survival Commission Invasive Species Specialist Group, IUCN, Gland, Switzerland.

Milner-Gulland, E.J., Bennett, E.L., Abernethy, K., Bakarr, M., Bodmer, R.E., Brashares, J. et al. (2003) Wild meat: the bigger picture. Trends in Ecology \& Evolution, 18, 351-357.

Mourão, G.D.M., Coutinho, M.E., Mauro, R., Tomas, W.M. \& Magnusson, W. (2002) Levantamentos aéreos de espécies introduzidas no Pantanal: porcos ferais (porco monteiro), gado bovino e búfalos. Embrapa Pantanal, Corumba, Brazil.

Paes, R.C.S., Ribeiro, O.C., Carneiro Monteiro, L.A.R., Figueiredo, A.O., Neto, A.A.C., Oliveira, J.M. et al. (2009) Enfermidades de ocorrência no porco monteiro (Sus scrofa) no Pantanal Sul-Mato-Grossense, Brasil. Suiform Soundings, 9, 29-34. REDFORD, K.H. (1992) The empty forest. Science, 42, 412-422.

Robinson, J.G. \& BennetT, E.L. (2000) Hunting for Sustainability in Tropical Forests. Columbia University Press, New York, USA.

Rosser, A.M. \& Mainka, S.A. (2002) Overexploitation and species extinctions. Conservation Biology, 16, 584-586.

Schaller, G.B. (1983) Mammals and their biomass on a Brazilian ranch. Arquivos de Zoologia, 31, 1-36.

Seidl, A.F., Vila de Silva, J.S. \& Moraes, A.S. (2001) Cattle ranching and deforestation in the Brazilian Pantanal. Ecological Economics, 36, 413-425.

Zimmermann, A., Walpole, M.J. \& Leader-Williams, N. (2005) Cattle ranchers' attitudes to conflicts with jaguar Panthera onca in the Pantanal of Brazil. Oryx, 39, 406-412.

\section{Biographical sketches}

Arnaud Desbiez has been working in the Pantanal since 2002. His current research includes the ecology of mammals, the interaction between native and alien species, and the sustainable use of forage resources. Alexine Keuroghlian has been working in the Pantanal since 2000. Her research interests include the ecology of peccaries, the sustainable use of natural resources and land management in the Pantanal. Ubiratan Piovezan's research interests include the management of feral pig populations and the sustainable use of wildlife by local communities in Brazil. RICHARD BODMER's current research focuses on the biology, conservation and sustainable use of Amazonian wildlife. Arnaud, Alexine and Richard are members of the IUCN Peccary Specialist Group. 